\title{
Recommendations for resetting the food system
}

\author{
Danielle Nierenberg ${ }^{1}$
}

Accepted: 25 April 2020 / Published online: 18 May 2020

(c) Springer Nature B.V. 2020

Since the lockdown began, my coping mechanism has been to listen. I'm usually traveling somewhere like Dakar or Des Moines to hear from farmers, chefs, policymakers, or scientists about how to fix a food system that I and many others have called broken. Now, I video-conference with experts about how COVID-19 is transforming the world's food system.

From the stories they share, it's clear that agriculture needed to be revolutionized pre-pandemic - and we can't return to the way things were. These unprecedented challenges provide enormous opportunities to create a food system that can't be broken-one that is truly regenerative and restorative, and that leaves no one behind.

\section{Combining high and low tech}

Since Friday, March 13th, U.S. farmers have had to pivot dramatically. As farmers' markets and restaurants closed, they were left without outlets to sell food. Digital technology is helping to change the way they do business. In Minnesota, the Mill City Farmers Market set up an online store for customers to choose products from individual farms and then pick up groceries via a drive-through market.

The National Young Farmers Coalition and the Glynwood Center for Regional Food and Farming are using Zoom meetings to provide advice on food safety. Old-fashioned phone trees are being set up so that farmers can share resources or simply check in on one another.

And for those who rely on SNAP benefits, Wholesome Wave is piloting an online system to deliver essentials. Pandemic or not, allowing SNAP clients to access food just as

This article is part of the Topical Collection: Agriculture, Food \& Covid-19.

Danielle Nierenberg

danielle@foodtank.com

1 President of Food Tank, New Orleans, USA easily as eaters who order food online will be a gamechanger, particularly for parents and the elderly.

\section{Making the invisible visible}

It's no secret that those harvesting, slaughtering, processing, preparing, distributing, and selling food are putting their lives at risk. Their essential-ness can't be denied-nor can the unfair and unjust labor practices and low wages that make them vulnerable.

Saru Jayaraman of One Fair Wage hopes that "when the \{restaurant $\}$ industry reemerges it can actually take care of its people and allow both employers and workers to thrive." That will mean better salaries-including a \$15 minimum wage-and universal unemployment insurance.

Companies who depend on food and farm workers are also stepping up, while others are regressing and suppressing workers' rights. Hazard pay, or "hero pay," is being implemented by companies like Stonyfield Organic, Farmer's Fridge, and Perdue Farms, yet companies like Trader Joe's are actively thwarting the rights of workers to form unionsthese actions will likely impact consumers' decisions over the long run.

\section{Food as medicine}

According to the CDC, people with diet-related diseasesdiabetes, obesity, hypertension - are at higher risk for severe COVID-19 infection.

Former U.S. Secretary of Agriculture Dan Glickman believes our diets can help flatten the curve of COVID-19. "What you eat has a lot to do with how healthy you are," he says, and eating plenty of fruits and vegetables and getting enough zinc and Vitamin D can help ward off disease. We "need farm diversity," he says, and farmers need flexibility to grow fruits and vegetables, rather than monoculture crops.

And school shutdowns, while necessary, mean that kids go hungry. According to the World Food Programme, 360 
million kids around the globe have lost access to school meal programs. Mara Fleishman of the Chef Ann Foundation says, "we are seeing how much kids rely on school food programs." In response, the Austin Independent School District is preparing free school meals for students and their guardians via curbside or bus stop delivery-and they've produced a video to show other districts how to replicate their innovation safely and effectively.

\section{Vote with Your Fork: and Your Vote}

COVID-19 shows how fragile our food and economic systems are-but we can reset. To fight the pandemic - and improve the food system-we need to reimagine how we grow and eat food, and how we mobilize for change.

Chef Dan Barber says we need to shine an uncomfortable light on local and regional food systems, which were built on shaking the hand of the farmer who grew your food. He suggests new models to help farmers add value to food in every possible sense-from soil health on up. A more complex value chain, Barber says, can mean adding more value, more nutrition, and more deliciousness to what we eat.

For Daniel Katz of The Overbrook Foundation, the best way to fight the pandemic is in November. "Everything starts with one solution, and that is voting. We need an administration that is pro-environment, pro-people, and pro-changing the system to rebuild a greener, safer world, we need an administration that shares that same vision."

And Mackenzie Feldman of the youth-led Sunrise Movement is inspired by young activists who have not been thwarted by COVID-19-they continue organizing online for a Green New Deal. A Deal that protects and respects workers and recognizes the ecosystem services farmers provide and ensures compensation for protecting biodiversity, building soil health, and mitigating climate change.

It's clear from these experts and others that we can't go back to normal. Normal left us vulnerable, and this crisis has widened the cracks in a food system already in need of repair. But this is our time to pivot. Right now, we can develop long-lasting solutions to nourish both people and the planet.

Publisher's Note Springer Nature remains neutral with regard to jurisdictional claims in published maps and institutional affiliations.

Danielle Nierenberg is co-founder and President of Food Tank, a nonprofit organization focused on building a global community for safe, healthy, nourished eaters. Danielle has an M.S. in Agriculture, Food, and Environment from the Tufts University Friedman School of Nutrition Science and Policy and spent two years volunteering for the Peace Corps in the Dominican Republic. 